\title{
ANALISIS IMBANGAN AIR EMBUNG JONGKONG KABUPATEN BANGKA TENGAH MELALUI KAPASITAS TAMPUNGAN
}

\author{
Miskar Maini \\ Email : miskar.maini@si.itera.ac.id \\ Mashuri \\ Email : mashuri@si.itera.ac.id
}

Program Studi Teknik Sipil Jurusan Teknologi Infrastruktur dan Kewilayahan Institut Teknologi Sumatera Kampus Terpadu ITERA, Jati Agung, Kabupaten Lampung Selatan

\begin{abstract}
ABSTRAK
Pengelolaan manajemen sumber daya air menjadi prioritas bagi Indonesia terutama pemanfaatan sumber daya air yang bersumber dari embung, sungai dan dari sumber lainnya. Sumber daya air embung (bekas penambangan) di Kabupaten Bangka Tengah mempunyai potensi sumber daya air yang cukup besar untuk dimanfaatkan. Embung Jongkong yang terletak di Kecamatan Koba Kabupaten Bangka Tengah merupakan salah satu embung yang sekarang ini sudah dimanfaatkan untuk keperluan air baku bagi Perusahan Daerah Air Minum (PDAM) di Kecamatan Koba Kabupaten Bangka Tengah Provinsi Bangka Belitung, namun masalah erosi lahan dan sedimentasi pada suatu embung dapat berpengaruh pada perubahan kapasitas tampungan yang dapat mempengaruhi umur operasi embung. Untuk itu perlu dilakukan analisis imbangan air embung antara ketersediaan air dengan kebutuhan air yang digunakan dengan metode Standar Operating Rule (SOR). Optimasi aliran yang masuk ketampungan sebagai ketersediaan air dianalisis menggunakan model NRECA dari tahun 2008-2018 dan menunjukan rerata debit maksimum dan minimum yang masuk ke tampungan dengan model NRECA adalah 0,259 MCM dan 0,016 MCM. Aliran yang masuk ke tampungan dibangkitkan dengan model Markov musim ganda selama 20 tahun (2019-2039) dan didapatkan debit bangkitan yang masuk ketampungan dengan rerata maksimum dan minimum adalah 0,280 MCM dan 0,017 MCM. Selanjutnya data debit yang dibangkitkan digunakan sebagai data aliran masuk ketampungan dalam pengaturan pola operasi standar (SOR) untuk mengetahui keandalan tampungan 20 tahun kedepan (2019-2039) didapatkan debit optimum pengambilan jika keandalan tampungan 100\% dengan target pelepasan $80 \%$ dengan debit distribusi 21,537 ltr/s Maka dapat disimpulkan bahwa debit optimum tidak mampu memenuhi kebutuhan air domestik dan non domestik masyarakat Kecamatan Koba Kabupaten Bangka Tengah pada tahun $2039\left(Q_{k e b}>Q_{k e t}\right)$ atau debit optimum hanya mampu melayani 48\% kebutuhan air masyarakat Kecamatan Koba Kabupaten Bangka Tengah pada tahun 2039.
\end{abstract}

Kata Kunci : Tampungan, NRECA, Markov, Kebutuhan, SOR, Keandalan.

\section{PENDAHULUAN}

Sumberdaya air embung (bekas penambangan) di Kabupaten Bangka Tengah mempunyai potensi sumber daya air yang cukup besar untuk dimanfaatkan. Terdapat lebih dari 100 jenis embung hasil bekas penambangan dengan kedalaman dan luas yang bervariasi. Embung 
Jongkong yang terletak di Kecamatan Koba Kabupaten Bangka Tengah merupakan salah satu embung yang sekarang ini sudah dimanfaatkan untuk keperluan air baku bagi Perusahan Daerah Air Minum (PDAM) di Kecamatan Koba Kabupaten Bangka Tengah Provinsi Bangka Belitung.

Semua embung atau reservoir yang dibentuk oleh bekas penambangan timah yang ada di pulau bangka di masa lampau yang membentuk tampungan air, baik dari aliran air tanah maupun aliran air hujan yang masuk ke dalam embung secara alami akan menjadi sasaran bagi terjadinya sedimentasi atau pengendapan.

Besarnya pengendapan ini sangat dipengaruhi oleh kondisi alam setempat serta kegiatan manusia yang dilakukan terhadap daerah tersebut. Pengendapan sedimen berlebihan yang masuk ke dalam embung akan menyebabkan berkurangnya volume tampungan suatu embung, yang pada akhirnya akan mempengaruhi operasi pemanfaatan air embung serta mengurangi umur layanan embung itu sendiri

Adapun tujuan dari penelitian ini adalah untuk menganalisis besaran ketersediaan air pada Tampungan Embung Jongkong Kabupaten Bangka Tengah pada tahun 2019-2034, untuk menganalisis kebutuhan air masyarakat Kecamatan Koba pada tahun 2034, dan untuk mengetahui Keandalan Tampungan Embung Jongkong Kabupaten Bangka Tengah pada tahun 2034.

\section{TINJAUAN PUSTAKA}

Styorini (2006), melakukan penelitian terhadap empat embung bekas penambangan timah yang disebut kolong di Pangkalpinang Provinsi Bangka Belitung yakni kolong Spritus, Kolong Keramba, Kolong Eks Tambang 25, dan Kolong Pidada. Simulasi menggunakan model NRECA dengan data hujan selama 10 tahun (1992-2001). Hasil yang diperoleh menunjukan bahwa dari keempat kolong tersebut ternyata Kolong Keramba dan Kolong Pidada memiliki potensi ketersediaan air yang mampu mencukupi keutuhan air baku untuk komplek perkantoran Pemprov Bangka Belitung. Rerata inflow Kolong Keramba bervariasi antara 19,68 1/s hingga 74,15 1/s, sedangkan Kolong Pidada rerata inflow nya bervariasi antara 31,70 1/s hingga 119,45 1/s. Kebutuhan air untuk komplek perkantoran berdasarkan analisis yang dilakukan sebesar 4,49 1/s dan 7,19 1/s, berarti terjadi surplus ketersediaan air cukup besar.

Sabri (2008) melakukan penelitian mengenai "Nilai Ekonomi Air Kolong Dam-3 Pemali Kabupaten Bangka ”, Hasil penelitian menunjukan rerata debit yang masuk ke kolong maksimum 0,401 1/s dan minimum 0,059 1/s. Debit bangkitan ratarata bulanan maksimum 1,05 MCM dan minimum 0,234 MCM. Keandalan kolong 98\% terjadi pada target pelepasan $75 \%$ dengan debit pengambilan maksimum 105 1/s. Jumlah NEA untuk kedua peruntukan (PDAM dan BBIS) sebesar Rp.5.262/. $\mathrm{m}^{3}$ untuk periode 5 tahun pertama, Rp. $7.596 / \mathrm{m}^{3}$ untuk periode 5 tahun kedua, dan untuk periode 5 tahun ketiga sebesar Rp. $10.559 / \mathrm{m}^{3}$. Alokasi air optimum yaitu 65 1/s untuk PDAM dan 40 1/s untuk BBIS, pada kondisi tersebut jumlah NPA kolong 
Dam-3 Pemali untuk periode yang sama secara berurutan masing-masing sebesar Rp. 6.846.138.032, Rp.9.924.585.995, dan Rp. 13.831.846.871,.

Akbarsyah (2014), melakukan penelitian dengan judul analisis ketersediaan dan pemanfaatan air Kolong Simpur Pemali. Analisis ketersediaan air dengan model NRECA kemudian dilakukan simulasi debit bangkitan model Markov untuk musim ganda dan menunjukan rerata debit yang masuk kekolong maksimum adalah 0,262 MCM dan debit minimum 0,042 MCM. Selanjutnya data debit bangkitan digunakan sebagai data aliran masuk pada simulasi Standard Operating Rule (SOR) dan hasil penelitian Keandalan kolong $99 \%$ terjadi pada target pelepasan $52 \%$ dengan debit pengambilan maksimum 26 liter/detik. Analisis terhadap kebutuhan air domestik penduduk Kecamatan Pemali dengan proyeksi 15 tahun kedepan sebesar 38,38 liter/detik, maka dapat disimpulkan bahwa debit optimum tidak mampu memenuhi kebutuhan air domestik penduduk Kecamatan Pemali pada tahun $2028\left(\mathrm{Q}_{\mathrm{keb}}>\mathrm{Q}_{\mathrm{opt}}\right)$.

\section{LANDASAN TEORI}

\section{Model NRECA}

Untuk melakukan analisis ketersediaan air di tampungan kolong dilakukan pendekatan dengan metode NRECA karena diasumsikan karakteristik fisik kolong memiliki kesamaan dengan embung (Fadillah Sabri, 2008). Langkah perhitungan mencakup 18 tahapan Menurut Puslitbang Pengairan DPU 1994.

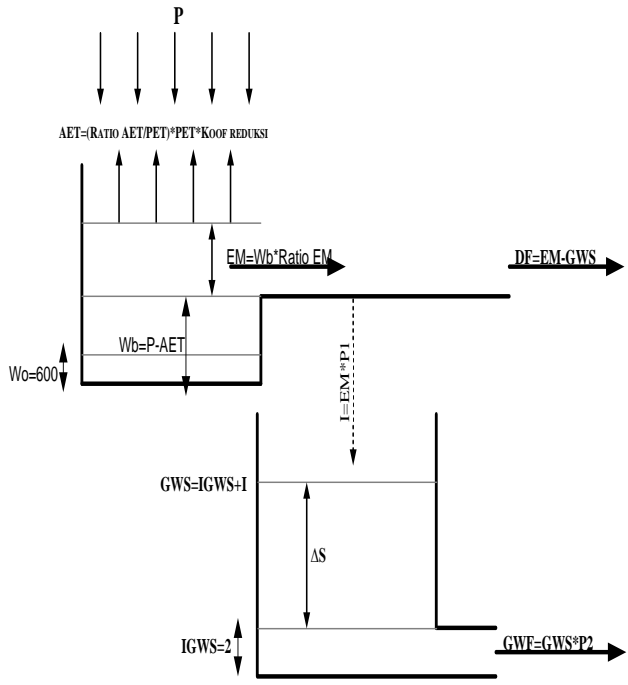

Gambar 1. Skema Struktur Model NRECA

Volume Potensial Tampungan Kolong

Volume Potensial Tampungan Kolong (Vp) diformulasikan dengan persamaan berikut ini.

$V p=\Sigma \mathrm{Vj}+10 \times \mathrm{Akl} \times \Sigma \mathrm{Rj}$

dengan:

$\mathrm{Vp}$ : volume potensial tampungan kolong $\left(\mathrm{m}^{3}\right)$,

$\Sigma \mathrm{Vj}$ : jumlah aliran total selama satu tahun $\left(\mathrm{m}^{3}\right)$,

$\Sigma \mathrm{Rj}$ : curah hujan total selama satu tahun $(\mathrm{mm})$,

Akl: luas permukaan tampungan kolong (ha)

\section{Jumlah Resapan (Vr)}

Besar resapan air di dalam kolong sangat tergantung dari sifat lulus air material dasar dan dinding kolong.

$\mathrm{Vr}=\mathrm{K} \times \mathrm{Vu}$

dengan:

$\mathrm{Vr}$ : jumlah resapan tahunan/bulanan $\left(\mathrm{m}^{3}\right)$ 
$\mathrm{Vu}$ : jumlah air untuk beberapa kebutuhan $\left(\mathrm{m}^{3}\right)$,

$\mathrm{K}$ : faktor yang nilainya tergantung dari sifat lulus air material dasar dan dinding kolong

$\mathrm{K}: 10 \%$, bila dasar dan dinding kolong praktis rapat air $(\mathrm{k} \leq 10-5 \mathrm{~cm} / \mathrm{d})$, termasuk penggunaan lapisan buatan (selimut lempung, geomembran, rubbersheet, semen tanah).

$\mathrm{K}: 25 \%$, bila dasar dan dinding kolong bersifat semi lulus air $(\mathrm{k}=10-3-10$ $4 \mathrm{~cm} / \mathrm{d}$ ).

\section{Data Bangkitan (Generated Data)}

Menurut Sabri, 2008 kegunaan pembangkitan data debit adalah:

1. Untuk memenuhi kebutuhan tampungan waduk dengan data sintetis.

2. Untuk membantu perancangan waduk akibat data kurang panjang.

3. Untuk simulasi pengoperasian waduk.

Rantai Markov adalah salah satu teknik perhitungan matematika yang digunakan dalam melakukan pemodelan bermacammacam kondisi yang digunakan untuk membantu dalam memperkirakan perubahan yang mungkin terjadi pada waktu yang akan datang dengan menggunakan variabel-variabel dinamis diwaktu yang lalu.

Persamaan model Markov untuk musim ganda (multi season) dengan mengikuti distribusi normal dapat dilihat pada persamaan 3 dan 4 :

$q i, j=\mu j+(\rho(j \times \sigma j / \sigma j-1) \times(q i, j-1-\mu j-1)+$ $t i, j \times \sigma j \times \sqrt{ }\left(l \rho(j)^{2}\right.$
$\rho(j)=[E\{(x i, j-\mu j) \times(x i-1, j-1-\mu j-1)\}] /(\sigma j \times$

$$
\sigma j-1)
$$

dimana:

$q i, j \quad$ : debit ke-i pada musim -j,

$\mu j \quad$ : nilai tengah/rata-rata nilai populasi musim $-\mathrm{j}$,

$\rho(j)$ : koefisien korelasi pasangan aliran yang berdekatan antara musim $\mathrm{j}$ 1dan musim -j,

oj : standar deviasi pada musim $-\mathrm{j}$,

$t i, j$ : bilangan acak distribusi normal pada waktu ke-i dan musim-j

\section{Operasi Pengaturan Pelepasan}

\section{Tampungan Air Kolong}

Penerapan model simulasi pada kolong untuk mengetahui keandalan kolong terhadap release (pelepasan/keluaran) dengan pendekatan pola pemanfaatan waduk/reservoir (kolong) (Fadillah Sabri, 2008).

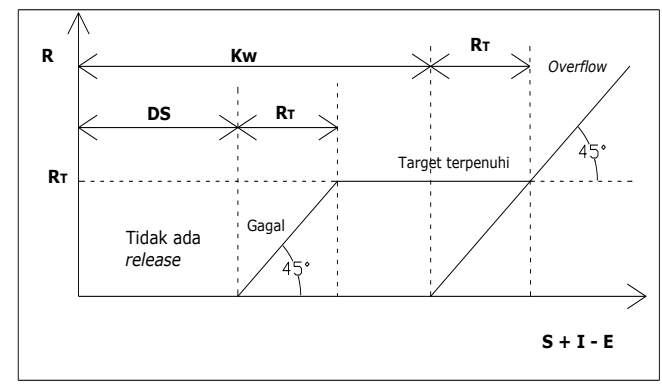

Gambar 2 Standard Operating Rule

Maksud dari grafik di atas prinsipnya simulasi, dilakukan dengan melakukan coba ulang nilai target release $R T$ sedemikian sehingga kriteria optimal penggunaan air dicapai. Simulasi tampungan kolong dihitung dengan persamaan sebagai berikut :

$S t+1=S t+I t-E t-O$

$0 \leq S_{t} \leq K w$ 
dengan :

$t \quad=$ jumlah diskret waktu (24 periode 15 harian)

$S_{t+1}=$ tampungan (storage) kolong saat awal ke-t $\left(\mathrm{m}^{3}\right)$

$S_{t} \quad=$ tampungan (storage) kolong saat akhir ke-t $\left(\mathrm{m}^{3}\right)$

$I_{t}=$ masukan (inflow) air kedalam kolong saat ke- $\mathrm{t}\left(\mathrm{m}^{3}\right)$

$E_{t} \quad=$ kehilangan air akibat evaporasi di kolong saat ke- $\mathrm{t}\left(\mathrm{m}^{3}\right)$

$O_{t}=$ pelepasan (outflow) air dari kolong saat ke-t $\left(\mathrm{m}^{3}\right)$

$K w=$ kapasitas waduk $\left(\mathrm{m}^{3}\right)$

Ruang untuk penampungan sedimen juga perlu dipersiapkan pada kolam/kolong sebagai tempat sedimentasi material yang terangkut ke dalam kolam/kolong. Besar ruang sedimen dalam perencanaan embung/waduk ditetapkan sebesar $5 \%$ dari volume tampungan maksimum (Puslitbang Air P.U., 1994).

\section{Kebutuhan Air Domestik dan Non Domestik (Non Irigasi)}

Analisis sektor domestik dan non domestik merupakan aspek penting dalam menganalisis kebutuhan penyediaan di masa mendatang. Analisis sektor domestik dan non domestik untuk masa mendatang dilaksanakan dengan dasar analisis pertumbuhan penduduk pada wilayah yang direncanakan (Kiki Komalia, 2012).

Kebutuhan air $=$ proyeksi jumlah penduduk $\times$ standar kebutuhan air....

Persamaan yang digunakan dalam memproyeksikan jumlah penduduk pada tahun ke-n adalah persamaan geometrik yang dapat dilihat lihat dalam persamaan 3.21 .

$P_{n}=P_{o} \times(1+i)^{n}$

dengan :

$P_{n}=$ Jumlah penduduk tahun rencana (jiwa)

$P_{o}=$ Jumlah penduduk tahun sekarang (jiwa)

$i=$ Persentase pertumbuhan penduduk (\%)

$n \quad=$ Tahun rencana

Untuk menghitung persentase pertambahan peduduk (i) digunakan persamaan:

$i=(\sqrt[n]{P n / P o})-1$

\section{Keandalan Tampungan Air}

Imbangan air merupakan nisbah antara kebutuhan air $(K A)$ dengan air tersedia (AT) (Sunjoto, 2005 dalam Fadillah Sabri, 2013) begitu juga keandalan tampungan secara matematis ditulis sebagai berikut:

$K T=\frac{K A}{A T} 100 \%$

\section{METODE PENELITIAN}

Penelitian dilakukan pada lokasi embung bekas penambangan timah biasa disebut (Kulong) Jongkong Kecamatan Koba yang Kabupaten Bangka Tengah Provinsi Kepulauan Bangka Belitung dengan variasi karakteristik luasan dan kedalaman embung tersebut.

Pengukuran luasan dan kedalaman embung menggunakan Ecosounder remote sensing. Analisis perhitungan ketersediaan air berdasarkan dari karakteristik embung 
dan data hujan dengan model NRECA selama 10 tahun (2009-2018). Keandalan penggunaan air embung dengan metode Standard Operating Rule (SOR) dengan menggunakan prediksi debit 20 tahun kedepan dengan simulasi data debit bangkitan dengan Model Markov

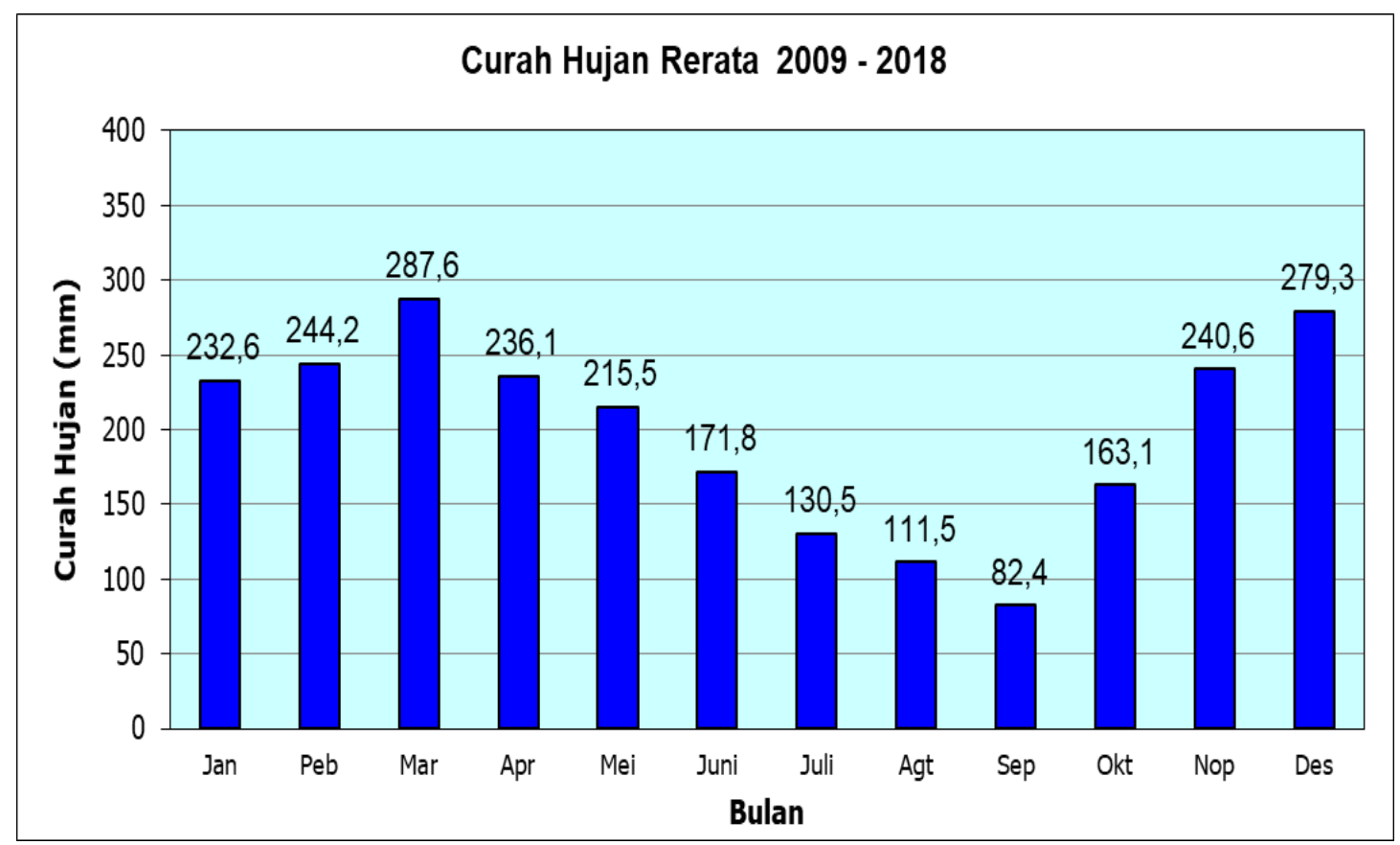

Gambar 3. Data Hujan Rerata Stasiun BMKG Pangkalpinang 2009 - 2018

Hasil pengumpulan data berupa data sekunder dan primer diolah dengan beberapa cara sebagai berikut:

1. Analisis ketersedian air menggunakan model NRECA dengan bantuan solver pada program MS. Excel.

2. Penguapan pada badan air (Eo) dianalisis dengan metode neraca energi, sedangkan analisis penguapan di daerah tangkapan air (ETo) menggunakan metode FAO Modified PenmanMonteith dengan bantuan software Cropwat for windows versi 4.3 .

3. Peta kontur, luas daerah tangkapan air, luas permukaan kolong, kedalaman dan volume dihitung dan dianalisis dengan menggunakan software Arc Veiw GIS versi 3.3 dan MapInfo Prof.9.0.
4. Analisis debit bangkitan menggunakan model Markov dan perhitungannya menggunakan program MS. Excel.

5. Program solver MS.Excel digunakan untuk melakukan simulasi operasi imbangan antara ketersedian dan kebutuhan air kolong (keandalan kolong) dengan metode Standard Operating Rule.

\section{HASIL DAN PEMBAHASAN \\ Deskripsi Pengukuran}

Pengukuran karakteristik Kulong berupa luas daerah tangkapan air, kedalaman embung, volume tampungan, luas permukaan embung diperoleh dengan cara menganalisis peta kontur hasil olahan data pengukuran GPS dan Sounding UAV (ecosounder remote sensing) dengan bantuan piranti lunak komputer (software) 
MapInfo dan ArcView GIS. Hasil embung 10,4411 Ha dan volume pengukuran menunjukan luas permukaan tampungan $850.614,1 \mathrm{~m}^{3}$

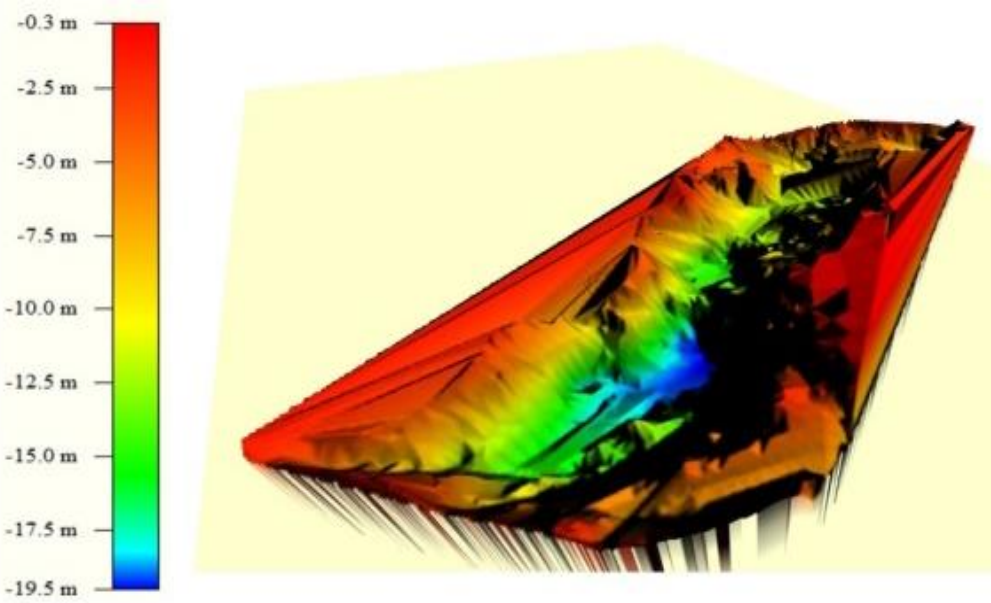

Gambar 4 hasil pengukuran menunjukan karakteristik luas permukaan embung dan kedalaman dengan menggunakan Ecosounder remote sensing.

\section{Analisis Ketersediaan Air Tampungan Existing Model NRECA}

Aliran masuk (inflow) pada Tampungan embung Jongkong dianalisis dengan menggunakan model NRECA untuk mendapatkan total aliran masuk pada Tampungan Embung Jongkong selama 10 tahun.

Untuk hasil optimasi menggunakan fasilitas solver pada
Software microsoft excel dengan model NRECA didapat tampungan kelengasan tanah awal (IMS) 552,76 mm, tampungan air tanah awal (IGWS) 271,56 mm, karakteristik tanah permukaan 0,1 , dan karakteristik lapisan dalam 0,5. Nilai koefisien limpasan atau runoff Coefficient (C) total yang dihitung berdasarkan hasil optimasi sebesar 0,199 untuk kala ulang 10 tahun.

Tabel 1. Rekapitulasi ketersediaan air pada Tampungan Embung Jongkong dengan model

NRECA Selama 10 Tahun (2009-2018) dalam MCM

\begin{tabular}{|c|c|c|c|c|c|c|c|c|c|c|c|c|}
\hline \multirow{2}{*}{ Tahun } & \multicolumn{12}{|c|}{ Bulan } \\
\hline & Jan & Feb & Mar & Apr & Mei & Jun & Jul & Aug & Sep & Okt & Nov & Des \\
\hline 2009 & 0,498 & 0,181 & 0,382 & 0,061 & 0,231 & 0,060 & 0,068 & 0,014 & 0,004 & 0,011 & 0,085 & 0,118 \\
\hline 2010 & 0,215 & 0,236 & 0,598 & 0,414 & 0,033 & 0,109 & 0,021 & 0,485 & 0,075 & 0,194 & 0,538 & 0,561 \\
\hline 2011 & 0,304 & 0,399 & 0,240 & 0,535 & 0,554 & 0,347 & 0,029 & 0,014 & 0,013 & 0,144 & 0,330 & 0,264 \\
\hline 2012 & 0,098 & 0,634 & 0,296 & 0,044 & 0,088 & 0,131 & 0,169 & 0,007 & 0,005 & 0,006 & 0,113 & 0,136 \\
\hline 2013 & 0,118 & 0,270 & 0,268 & 0,182 & 0,288 & 0,024 & 0,206 & 0,016 & 0,028 & 0,072 & 0,360 & 0,583 \\
\hline 2014 & 0,185 & 0,019 & 0,015 & 0,339 & 0,077 & 0,016 & 0,017 & 0,015 & 0,001 & 0,004 & 0,024 & 0,160 \\
\hline 2015 & 0,053 & 0,013 & 0,282 & 0,173 & 0,020 & 0,012 & 0,004 & 0,002 & 0,000 & 0,004 & $-0,004$ & 0,035 \\
\hline 2016 & 0,073 & 0,299 & 0,341 & 0,266 & 0,230 & 0,114 & 0,014 & 0,022 & 0,005 & 0,078 & 0,019 & 0,015 \\
\hline 2017 & 0,277 & 0,115 & 0,118 & 0,206 & 0,148 & 0,012 & 0,023 & 0,016 & 0,010 & 0,022 & 0,098 & 0,238 \\
\hline 2018 & 0,015 & 0,006 & 0,053 & 0,120 & 0,200 & 0,416 & 0,020 & 0,008 & 0,020 & 0,015 & 0,107 & 0,228 \\
\hline
\end{tabular}




\begin{tabular}{|c|c|c|c|c|c|c|c|c|c|c|c|c|}
\hline \multirow{2}{*}{ Tahun } & \multicolumn{12}{|c|}{ Bulan } \\
\hline & Jan & Feb & Mar & Apr & Mei & Jun & Jul & Aug & Sep & Okt & Nov & Des \\
\hline Jumlah & 1,837 & 2,172 & 2,593 & 2,339 & 1,868 & 1,240 & 0,572 & 0,601 & 0,162 & 0,552 & 1,670 & 2,337 \\
\hline Rata-rata & 0,184 & 0,217 & 0,259 & 0,234 & 0,187 & 0,124 & 0,057 & 0,060 & 0,016 & 0,055 & 0,167 & 0,234 \\
\hline Aliran max & 0,259 & \multicolumn{4}{|c|}{ terjadi pada bulan Maret } & & & & & & & \\
\hline Aliran min & 0,016 & \multicolumn{4}{|c|}{ terjadi pada bulan September } & & & & & & & \\
\hline
\end{tabular}

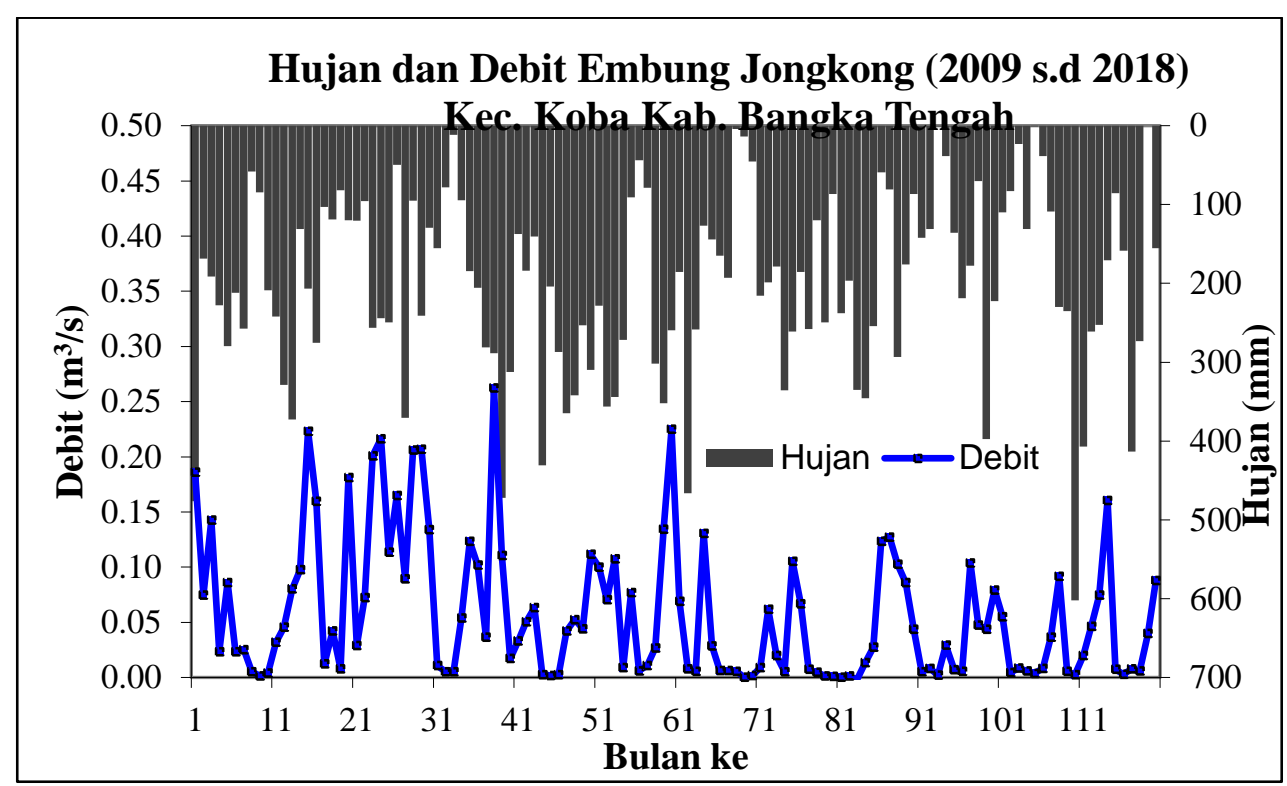

Gambar 5 Grafik hubungan antara hujan bulanan dan debit bulanan embung Jongkong data klimatologi tahun 2009-2018

Optimasi aliran yang masuk ketampungan sebagai ketersediaan air dianalisis menggunakan model NRECA dari tahun 2008-2018 dan menunjukan rerata debit maksimum dan minimum yang masuk ke tampungan dengan model NRECA adalah 0,259 MCM dan 0,016 MCM.

Analisis Ketersediaan Air Tampungan Prediksi 20 Tahun Kedepan Dengan Model Markov
Untuk membangkitkan debit yang masuk ke tampungan dari tahun 2018-2039 digunakan model Markov musim ganda seperti yang disajikan pada tabel 6. Aliran yang masuk ke tampungan dibangkitkan dengan model Markov musim ganda selama 20 tahun (2019-2039) dan didapatkan debit bangkitan yang masuk ketampungan dengan rerata maksimum dan minimum adalah 0,280 MCM dan 0,017 MCM.

Tabel 2. Hasil ketersediaan air dengan model Markov (2019 - 2034)

\begin{tabular}{|l|l|l|l|l|l|l|l|l|l|l|l|l|}
\hline \multicolumn{1}{|l|}{ Simulasi (MCM) } \\
\hline Tahun & Jan & Feb & Mar & Apr & Mei & Juni & Juli & Agst & Sept & Okt & Nov & Des \\
\hline 2019 & 0,145 & 0,232 & 0,285 & 0,257 & 0,243 & 0,149 & 0,047 & 0,081 & 0,020 & 0,070 & 0,258 & 0,354 \\
\hline 2020 & 0,174 & 0,234 & 0,282 & 0,264 & 0,173 & 0,169 & 0,058 & 0,018 & 0,017 & 0,072 & 0,128 & 0,149 \\
\hline 2021 & 0,195 & 0,247 & 0,306 & 0,233 & 0,237 & 0,187 & 0,065 & 0,056 & 0,016 & 0,166 & 0,074 & 0,220 \\
\hline
\end{tabular}




\begin{tabular}{|c|c|c|c|c|c|c|c|c|c|c|c|c|}
\hline \multicolumn{13}{|c|}{ Simulasi (MCM) } \\
\hline Tahun & Jan & Feb & Mar & Apr & Mei & Juni & Juli & Agst & Sept & Okt & Nov & Des \\
\hline 2022 & 0,181 & 0,206 & 0,318 & 0,209 & 0,271 & 0,176 & 0,059 & 0,054 & 0,020 & 0,142 & 0,124 & 0,218 \\
\hline 2023 & 0,199 & 0,203 & 0,245 & 0,268 & 0,198 & 0,208 & 0,059 & 0,049 & 0,020 & 0,136 & 0,114 & 0,188 \\
\hline 2024 & 0,214 & 0,285 & 0,237 & 0,299 & 0,214 & 0,210 & 0,043 & 0,043 & 0,017 & 0,116 & 0,101 & 0,191 \\
\hline 2025 & 0,222 & 0,234 & 0,290 & 0,272 & 0,192 & 0,178 & 0,059 & 0,069 & 0,016 & 0,185 & 0,083 & 0,260 \\
\hline 2026 & 0,206 & 0,251 & 0,294 & 0,260 & 0,227 & 0,196 & 0,050 & 0,005 & 0,020 & 0,024 & 0,114 & 0,113 \\
\hline 2027 & 0,236 & 0,206 & 0,266 & 0,287 & 0,196 & 0,187 & 0,060 & 0,000 & 0,016 & 0,023 & 0,114 & 0,121 \\
\hline 2028 & 0,231 & 0,217 & 0,237 & 0,268 & 0,217 & 0,171 & 0,060 & 0,060 & 0,018 & 0,166 & 0,107 & 0,224 \\
\hline 2029 & 0,196 & 0,308 & 0,260 & 0,254 & 0,186 & 0,170 & 0,056 & 0,058 & 0,015 & 0,152 & 0,089 & 0,240 \\
\hline 2030 & 0,217 & 0,196 & 0,313 & 0,249 & 0,236 & 0,185 & 0,071 & 0,058 & 0,019 & 0,155 & 0,084 & 0,247 \\
\hline 2031 & 0,195 & 0,293 & 0,252 & 0,271 & 0,235 & 0,196 & 0,039 & 0,012 & 0,015 & 0,051 & 0,067 & 0,131 \\
\hline 2032 & 0,260 & 0,202 & 0,270 & 0,241 & 0,185 & 0,177 & 0,047 & 0,017 & 0,016 & 0,060 & 0,078 & 0,128 \\
\hline 2033 & 0,172 & 0,200 & 0,271 & 0,242 & 0,239 & 0,165 & 0,076 & 0,040 & 0,021 & 0,104 & 0,121 & 0,183 \\
\hline 2034 & 0,205 & 0,213 & 0,279 & 0,242 & 0,190 & 0,183 & 0,075 & 0,000 & 0,017 & 0,000 & 0,096 & 0,097 \\
\hline 2035 & 0,186 & 0,287 & 0,227 & 0,253 & 0,188 & 0,204 & 0,048 & 0,000 & 0,016 & 0,019 & 0,078 & 0,081 \\
\hline 2036 & 0,189 & 0,234 & 0,289 & 0,252 & 0,241 & 0,197 & 0,051 & 0,044 & 0,018 & 0,124 & 0,101 & 0,193 \\
\hline 2037 & 0,164 & 0,271 & 0,297 & 0,268 & 0,254 & 0,159 & 0,053 & 0,048 & 0,016 & 0,123 & 0,087 & 0,192 \\
\hline 2038 & 0,221 & 0,236 & 0,323 & 0,277 & 0,231 & 0,184 & 0,043 & 0,032 & 0,017 & 0,098 & 0,097 & 0,199 \\
\hline 2039 & 0,231 & 0,236 & 0,330 & 0,271 & 0,279 & 0,178 & 0,055 & 0,065 & 0,016 & 0,168 & 0,087 & 0,260 \\
\hline Markov & 0,202 & $\mathbf{0 , 2 3 8}$ & $\mathbf{0 , 2 8 0}$ & 0,259 & 0,221 & 0,182 & $\mathbf{0 , 0 5 6}$ & $\mathbf{0 , 0 3 8}$ & 0,017 & $\mathbf{0 , 1 0 3}$ & 0,105 & 0,190 \\
\hline NRECA & 0,184 & 0,217 & 0,259 & 0,234 & 0,187 & 0,124 & $\mathbf{0 , 0 5 7}$ & $\mathbf{0 , 0 6 0}$ & $\mathbf{0 , 0 1 6}$ & $\mathbf{0 , 0 5 5}$ & $\mathbf{0 , 1 6 7}$ & 0,234 \\
\hline Jumlah & 4,239 & 4,994 & 5,871 & 5,436 & 4,631 & 3,829 & 1,173 & $\mathbf{0 , 8 0 7}$ & 0,365 & 2,155 & 2,203 & 3,987 \\
\hline Rerata & 0,202 & $\mathbf{0 , 2 3 8}$ & $\mathbf{0 , 2 8 0}$ & 0,259 & 0,221 & 0,182 & 0,056 & $\mathbf{0 , 0 3 8}$ & 0,017 & $\mathbf{0 , 1 0 3}$ & 0,105 & 0,190 \\
\hline Aliran max & 0,280 & . & do b & in $\mathrm{Ma}$ & & & & & & & & \\
\hline Aliran min & 0,017 & terja & $\mathrm{da}$ & $\mathrm{an} \mathrm{Sep}$ & $\mathrm{er}$ & & & & & & & \\
\hline
\end{tabular}

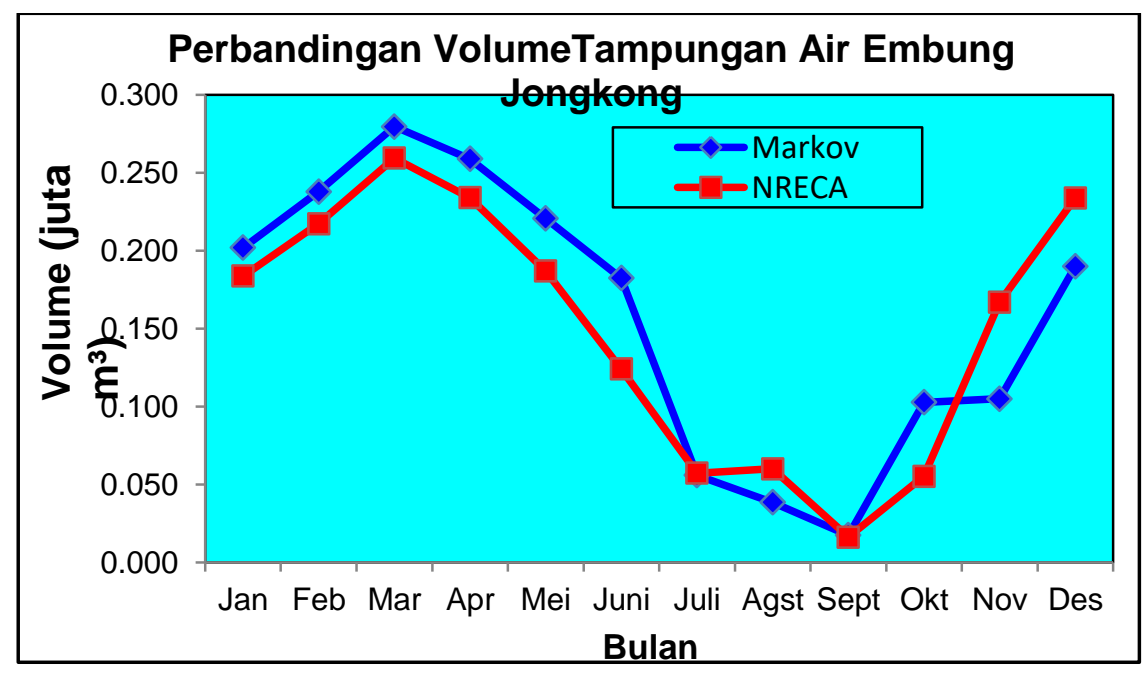

Gambar 6. Grafik perbandingan antara debit NRECA terhadap debit bangkitan model Markov yang masuk ke tampungan 
Analisis Kebutuhan Air Domestik dan

\section{Non Domestik}

Data jumlah penduduk dan fasilitas sosial ekonomi digunakan untuk menghitung kebutuhan air domestik dan non domestik masyarakat Kecamatan Koba. Jumlah penduduk dianalisis menggunakan persamaan geometrik dan digunakan sebagai dasar dalam menentukan kebutuhan air domestik dan non domestik. Berdasarkan data jumlah penduduk Kecamatan Koba tahun 20132016, maka didapatkan persentase pertumbuhan penduduk adalah $1,59 \%$.
Selanjutnya ditentukan kebutuhan air bersih domestik berdasarkan standar kebutuhan air sebesar 15,51 ltr/s. Sedangkan kebutuhan air non domestik untuk berbagai fasilitas sebesar 4,65 ltr/s. Kebutuhan air untuk industri sebesar 1,55 ltr/s serta kebutuhan pengganti kehilangan air sebesar 5,21 ltr/s. Maka total kebutuhan air 11 desa yang ada di Kecamatan Koba kebutuhan air domestik, industri dan non domestik serta faktor kehilangan air Kecamatan Koba sebesar 26,921 1tr/s dengan tingkat pelayanan distribusi sebesar $60 \%$ dari jumlah penduduk.

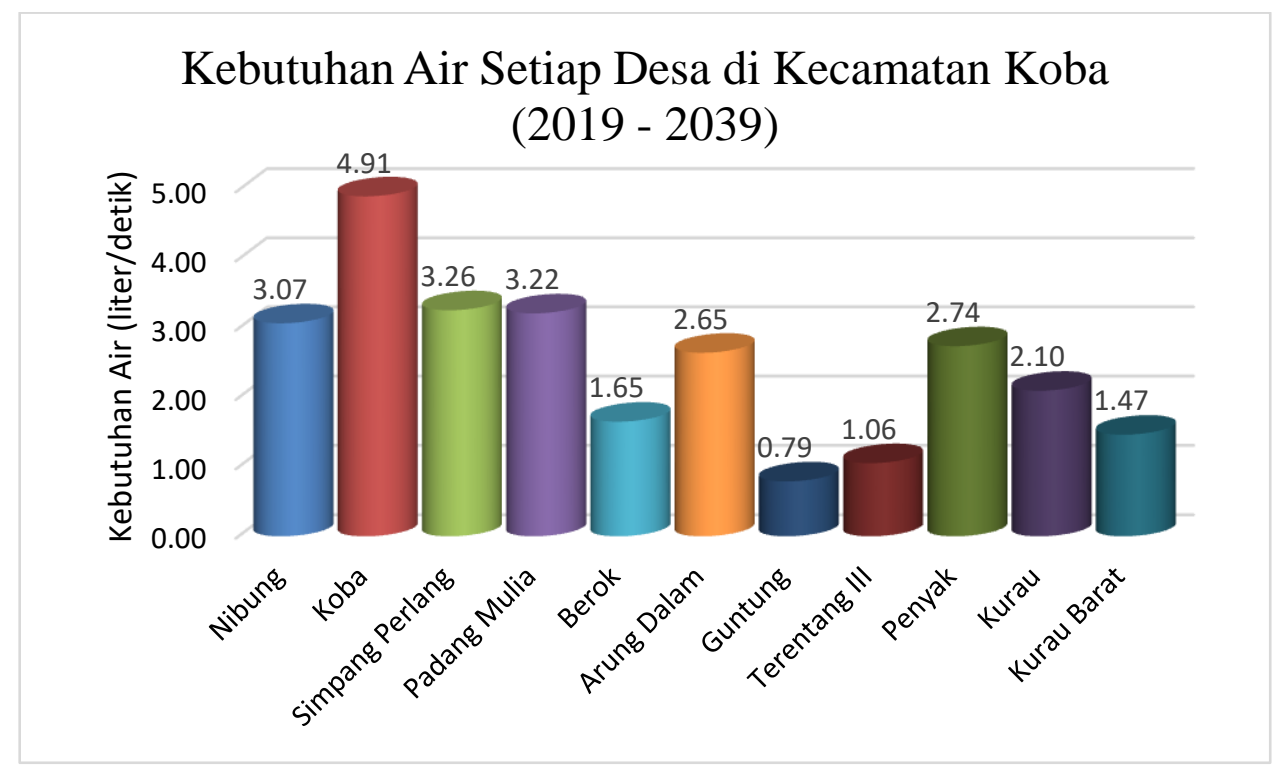

Gambar 7. Perbandingan Kebutuhan Air Setiap Desa di Kecamatan Koba (2019-2039)

\section{Analisis Karakteristik Tampungan Embung Jongkong}

Analisis karakteristik tampungan kondisi existing yang digunakan sebagai input data dalam Standard Operating Rule untuk mengetahui kondisi awal bulan dan kondisi akhir bulan pada tampungan. Berdasarkan hasil analisis kedalaman embung Jongkong adalah 19,20 m dengan volume embung sebesar 879.616,00 $\mathrm{m}^{3}$ dan luas permukaan air kulong sebesar 135.800,00 $\mathrm{m}^{2}$. Bentuk kurva hubungan antar variabel Kulong Jungkong Ali hasil estimasi trendline dan analisis regresi ditunjukkan pada Gambar5. 


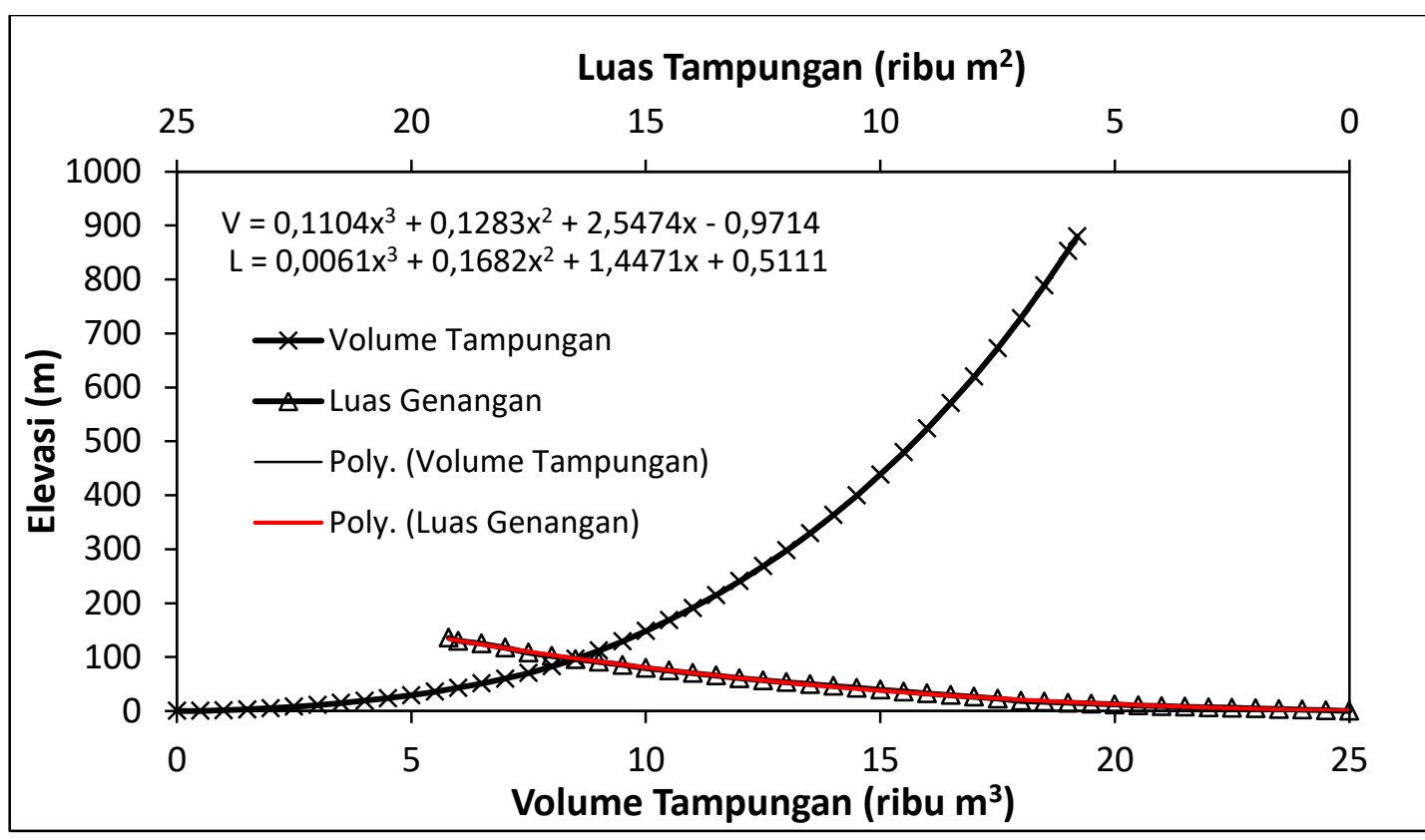

Gambar 8. Kurva hubungan elevasi dengan luas genangan dan volume tampungan

Pada Gambar 8 dapat dilihat persamaan hubungan elevasi embung (m) terhadap volume tampungan (ribu $\mathrm{m}^{3}$ ) adalah

$\mathrm{V}=0,1104 \mathrm{x}^{3}+0,1283 \mathrm{x}^{2}+2,5474 \mathrm{x}-$ 0,9714

dengan $\quad \mathrm{v}$ : volume kulong (ribu $\mathrm{m}^{3}$ ) $\mathrm{x}$ : elevasi kulong $(\mathrm{m})$

sedangkan pada Gambar 5 dapat dilihat persamaan hubungan elevasi embung (m) terhadap luas genangan (ribu $\mathrm{m}^{2}$ ) adalah

$\mathrm{L}=0,0061 \mathrm{x}^{3}+0,1682 \mathrm{x}^{2}+1,4471 \mathrm{x}+$ 0,5111

Dengan L : luas genangan (ribu $\mathrm{m}^{2}$ ) $\mathrm{x}$ : elevasi kulong $(\mathrm{m})$

Simulasi Standard Operating Rule Tampungan Embung Jongkong

Langkah-langkah dalam analisis simulasi Standard Operating Rule adalah memasukkan data debit bangkitan sebagai inflow kemudian memasukan data evaporasi pada tampungan embung berdasarkan rekapitulasi data dari Stasiun Meteorologi Pangkalpinang. Untuk kondisi karakteristik tampungan digunakan analisis regresi dengan bantuan trendline. Untuk Outflow digunakan kebutuhan yang digunakan Sistem Penyediaan Air Minum (SPAM) dan jumlah volume resapan dan menghitung kondisi akhir bulan sama dengan persamaan yang digunakan pada awal bulan.

Hasil analisis simulasi SOR untuk Kulong Jungkong Ali Kecamatan Koba hanya memiliki satu bentuk simulasi ideal. Hal ini dikarenakan Embung Jongkong yang memiliki debit ketersediaan air rerata sebesar 57,182 1tr/s mampu memenuhi seluruh debit total kebutuhan air di Kecamatan Koba sebesar 26, 921 ltr/s 
Tabel 3 Hasil Simulasi SOR Embung Jongkong di Sebelas Desa di Kecamatan Koba selama 20 tahun (2019-2039)

\begin{tabular}{|l|l|l|l|l|l|}
\hline \multirow{2}{*}{ No } & \multirow{2}{*}{$\begin{array}{l}\text { Target Pelepasan } \\
(\%)\end{array}$} & \multirow{2}{*}{ Keandalan $(\%)$} & $\begin{array}{l}\text { Distribusi } \\
\text { Kebutuhan }\end{array}$ & Jumlah & $\begin{array}{l}\text { Kegagalan 3 } \\
\text { Kali Berurutan }\end{array}$ \\
\cline { 4 - 6 } & & Domestik (1/s) & Kegagalan & \\
\hline 1 & 100 & $96 \%$ & 26,921 & 10 & Ada \\
\hline 2 & 95 & $96 \%$ & 25,575 & 9 & Ada \\
\hline 3 & 90 & $98 \%$ & 24,229 & 4 & Ada \\
\hline 4 & 85 & $100 \%$ & 22,883 & 1 & Ada \\
\hline 5 & 80 & $100 \%$ & 21,537 & 0 & Tidak Ada \\
\hline
\end{tabular}

Sumber : Analisis, 2019

Jika keandalan tampungan atau reliabilitas 96\% dengan target pelepasan 100\% dengan debit distribusi 26,921 $1 \mathrm{tr} / \mathrm{s}$ maka sepanjang 20 tahun yang direncanakan SPAM Embung Jongkong mengalami kegagalan 10 kali, dengan banyak nya kegagalan tetapi masih bisa mencukupi $60 \%$ kebutuhan air dari SPAM dan kebutuhan seluruh masyarakat Kecamatan Koba dari yang di rencanakan. Sedangkan jika keandalan tampungan $100 \%$ dengan target pelepasan $80 \%$ dengan debit disribusi 21,537 ltr/s tidak ada kegagalan sepanjang 20 tahun, tetapi tidak bisa mencukupi semua kebutuhan air dari SPAM seluruh masyarakat Kecamatan Koba sebesar 26, 921 ltr/s..

Berdasarkan Tabel 7.34 diketahui bahwa target release $80 \%$ menghasilkan keandalan $100 \%$ dengan tidak terjadi kegagalan selama 20 tahun waktu rencana. Hal ini berarti bahwa keseluruhan kebutuhan air Embung Jongkong belum mampu terpenuhi oleh kapasitas tampungan Embung Jongkong jika target distribusi air harus $100 \%$ untuk bisa mencukupi kebutuhan dari SPAM seluruh masyarakat Kecamatan Koba.

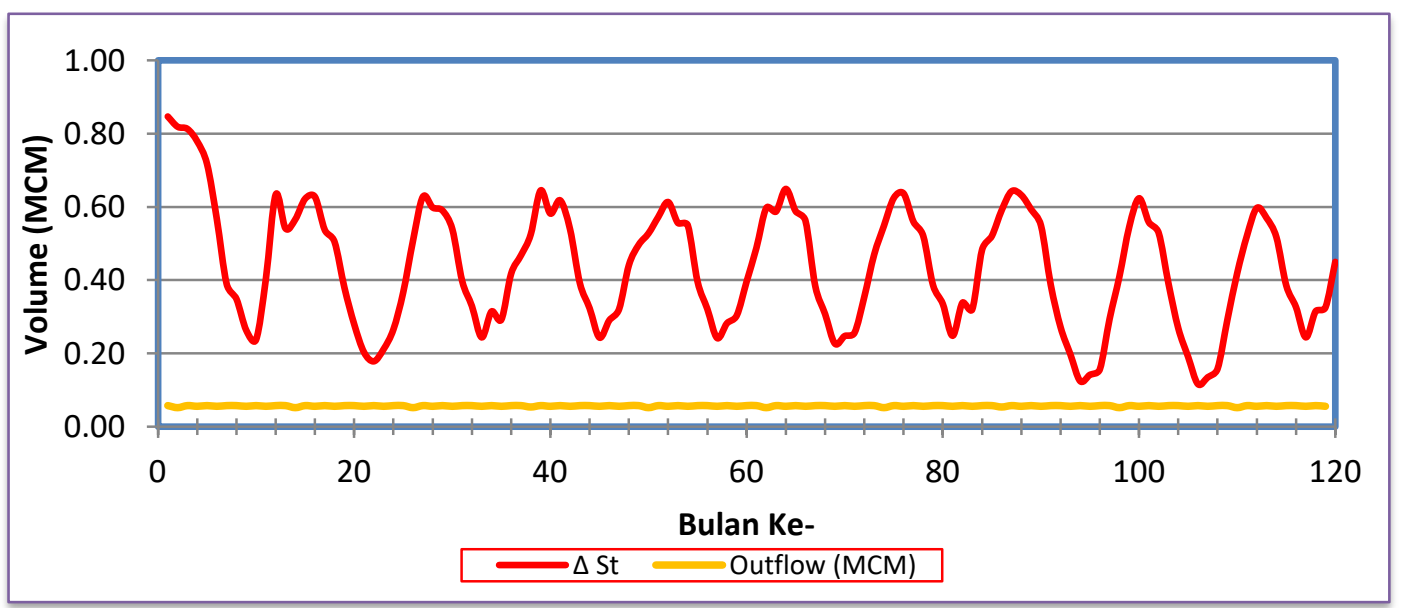

Gambar 9 Grafik Perubahan Tampungan Air Embung Jongkong Target Release 80\% dan Keandalan $100 \%$ tanpa kegagalan 
Analisis Keandalan Tampungan SPAM Embung Jongkong

Dalam analisis Keandalan

Tampungan SPAM untuk memenuhi kebutuhan air domestik dan non domestik masyarakat Kecamatan Koba diperlukan nilai debit optimum. Debit optimum yang akan digunakan didapat berdasarkan simulasi SOR untuk perencanaan 20 tahun kedepan yaitu $0,0215 \mathrm{~m}^{3} / \mathrm{s}$ dan proyeksi jumlah penduduk 20 tahun kedepan untuk mendapatkan jumlah kebutuhan air domestik dan non domestik penduduk Kecamatan Koba yaitu sebesar $0,0269 \mathrm{~m}^{3} / \mathrm{s}$. Berdasarkan hasil perhitungan antara debit optimum sebesar $0,0215 \mathrm{~m}^{3} / \mathrm{s}$ dan debit kebutuhan air domestik dan non domestik sebesar $0,0269 \mathrm{~m}^{3} / \mathrm{s}$, maka dapat ditarik kesimpulan bahwa ketersediaan air pada Embung Jongkong untuk 20 tahun kedepan hanya dapat melayani $48 \%$ kebutuhan air $\left(\mathrm{Q}_{\mathrm{op}}<\mathrm{Q}_{\mathrm{keb}}\right)$ penduduk Kecamatan Koba. Jadi, dari total seluruh masyarakat Kecamatan Koba bisa diketahui bahwa SPAM Kecamatan Koba bisa melayani 11.779 jiwa berdasarkan kebutuhan air domestik. Dapat disimpulkan bahwa Keandalan Tampungan Embung Jongkong belum dapat memenuhi seluruh kebutuhan air Masyarakat Kecamatan Koba karena keterbatasan ketersediaan air yang dimiliki tampungan embung tersebut.

\section{KESIMPULAN}

1. Ketersediaan air yang tertampung pada Embung Jongkong dianalisis menggunakan model NRECA. Hasil Optimasi aliran yang masuk ketampungan sebagai ketersediaan air dianalisis menggunakan model NRECA dari tahun 2008-2018 dan menunjukan rerata debit maksimum dan minimum yang masuk ke tampungan dengan model NRECA adalah 0,259 MCM dan 0,016 MCM. Sedangkakan aliran yang masuk ke tampungan dibangkitkan dengan model Markov musim ganda selama 20 tahun (2019-2039) dan didapatkan debit bangkitan yang masuk ketampungan dengan rerata maksimum dan minimum adalah 0,280 MCM dan 0,017 MCM

2. Kebutuhan air domestik dan non domestik masyarakat Kecamatan Koba tahun 2039 didapatkan yaitu $0,0269 \mathrm{~m}^{3} / \mathrm{s}$

3. Keandalan Tampungan SPAM pada tahun 2039 yaitu $48 \%$ dari total seluruh kebutuhan air masyarakat Kecamatan Koba dan bisa melayani 11.779 jiwa berdasarkan kebutuhan air domestik dan non domestik, sehingga kapasitas tampungan Embung Jongkong tidak mampu untuk memenuhi semua kebutuhan air masyarakat Kecamatan Koba secara keseluruhan.

\section{UCAPAN TERIMAKASIH}

Ucapan terima kasih disampaikan kepada Lembaga Penelitian, Pengabdian Kepada Masyarakat, dan Penjaminan Mutu Pendidikan (LP3) Institut Teknologi Sumatera, yang telah memberikan support dana penelitian (Penelitian Hibah ITERA SMART Tahun 2019) sehingga pelaksanaan penelitian ini dapat berjalan dengan baik. 


\section{DAFTAR PUSTAKA}

Akbarsyah. 2014. Analisis Ketersediaan dan Pemanfaatan Air Kolong Simpur Kecamatan Pemali. UBB, Pangkalpinang.

Fadillah Sabri. 2008. Nilai Ekonomi Air Kolong DAM-3 Pemali Kabupaten Bangka. UGM, Yogyakarta.

Fadillah Sabri. 2015. Pengelolaan Sumberdaya Kolong. Citra books; Palembang.

Kiki Komalia dkk. 2012. Analisis Pemakaian Air Bersih ( PDAM ) Untuk Kota Pematang Siantar. USU, Medan.

Ven Te Chow, Maidment, David R. \& Mays, Larry W. 1988. Applied Hydrology. McGraw-Hill Book Company. 